\title{
A sisakos sáska (Acrida ungarica: Orthoptera, Acrididae) újabb adatai a Dél-Dunántúlon
}

\author{
ERDŐS LÁSZLÓ $^{1,2}$, KOVÁCS ATTILA $^{3}$ és PUSKÁS GELLÉRT ${ }^{4 *}$ \\ ${ }^{1}$ Ökológiai Kutatóközpont Ökológiai és Botanikai Intézet, 2163 Vácrátót, Alkotmány utca 2-4. \\ ${ }^{2}$ MTA-DE Lendület Funkcionális és Restaurációs Ökológiai Kutatócsoport, 4032 Debrecen, Egyetem tér 1. \\ ${ }^{3}$ Magyar Természettudományi Múzeum, Bakonyi Természettudományi Múzeum, \\ 8420 Zirc, Rákóczi Ferenc tér 3-5. \\ ${ }^{4}$ Magyar Természettudományi Múzeum, Állattár, 1088 Budapest, Baross utca 13. \\ *E-mail: saksup@gmail.com
}

\begin{abstract}
Kivonat. A Magyarországon védett és vöröskönyves sisakos sáska (Acrida ungarica) egy-egy korábban ismeretlen populációjára vonatkozó adatokat közlünk a Mecsekből és a Villányi-hegységből. A Mecsekben a fajnak eddig egyetlen adatát publikálták 1957-ben, míg a Villányi-hegységben két ismert lelöhelye volt, utolsó onnan közölt adata 1971-ből származik.
\end{abstract}

Kulcsszavak: egyenesszárnyúak, faunisztika, Jakab-hegy, konzervációbiológia, száraz gyepek

\section{Bevezetés}

A sisakos sáska (Acrida ungarica HERBST, 1786) pontomediterrán-turkesztáni elterjedésű rovar (VARGA et al. 1990). Európában elterjedésének súlypontja a Földközi-tenger térségére esik (az Ibériai-félsziget déli és keleti részei, Délkelet-Franciaország, Appenninifélsziget, Balkán) (HOCHKIRCH et al. 2016). Természetes areája a Kárpát-medencében éri el északi határát (SZÖVÉNYI et al. 2007), csehországi előfordulásai minden bizonnyal a mediterrán térségből történt betelepítésekből erednek (HoLUŠA et al. 2013). Szlovákiában viszszaszorulóban van (KRIŠTíN et al. 2004). Ausztriából kipusztult az 1960-as évek vége és a '90-es évek eleje között (BIERINGER 2017), azonban 2018-ban egy új állományára bukkantak a Fertö-tó környékén - ez lehet reliktum populáció és Magyarország felöl való betelepülés is (BIERINGER et al. 2018).

Hazánkban az Alföld egyes részein gyakori (Kiskunság: RÁCZ 1986; Körös-Maros Nemzeti Park: NAGY \& SzÖVÉNYI 1998, 1999, DELI 2015; Hortobágy: NAGY 1983, NAGY et al. 2019; Nyírség: NAGY 1947), a Dunántúlon elsősorban a Kisalföld és a Mezőföld tájakra jellemző (ÁBRAHÁM 1992, RÁCZ et al. 2005, PÁPAI \& KRAUSZ 2008, KRAUSZ \& PÁPAI 2010, KENYERES \& RÁCZ 2011, SZÖVÉNYI \& PUSKÁS 2011, KENYERES et al. 2013). A Dunántúl dombvidéki tájain csak szórványosan fordul elő: ismert a Bakonyból (KENYERES 2006, 2014, KENYERES \& RÁCZ 2011), a Balaton-felvidékről (RÁCZ et al. 2005, KENYERES \& RÁCZ 2011, KeNYERES 2014, 2019), a Somogyi- (ÁBrAHÁM 1992, NAGY \& SZÖVÉNYI 2001, NAGY et al. 2003, KISBENEDEK 2015), a Tolnai-dombvidékről (KENYERES 
et al. 2014), a Mecsekböl (SZÖVÉNYI et al. 2007) és a Villányi-hegységböl (RÁCZ \& VARGA 1985, ÁBRAHÁM 1992, NAGY 1999, NAGY \& NAGY 2000).

A sisakos sáska Magyarországon vörös könyves faj (VARGA et al. 1990). Védett, pénzben kifejezett értéke egyedenként $50000 \mathrm{Ft}$. Az IUCN vörös listáján a nem veszélyeztetett ('least concern') kategóriába tartozik (HocHKIRCH et al. 2016).

\section{Anyag és módszer}

2019 augusztusában és szeptemberében botanikai valamint faunisztikai vizsgálatokat végeztünk a Villányi-hegység és a Mecsek területén. A sisakos sáska példányok észlelése vizuális megfigyeléssel és fühálós rovargyüjtéssel történt. Mivel egyértelmüen azonosítható, de védett és lokálisan ritka fajról van szó, a példányok nem kerültek begyüjtésre, bizonyító erejü fényképek azonban készültek róluk (1. ábra).

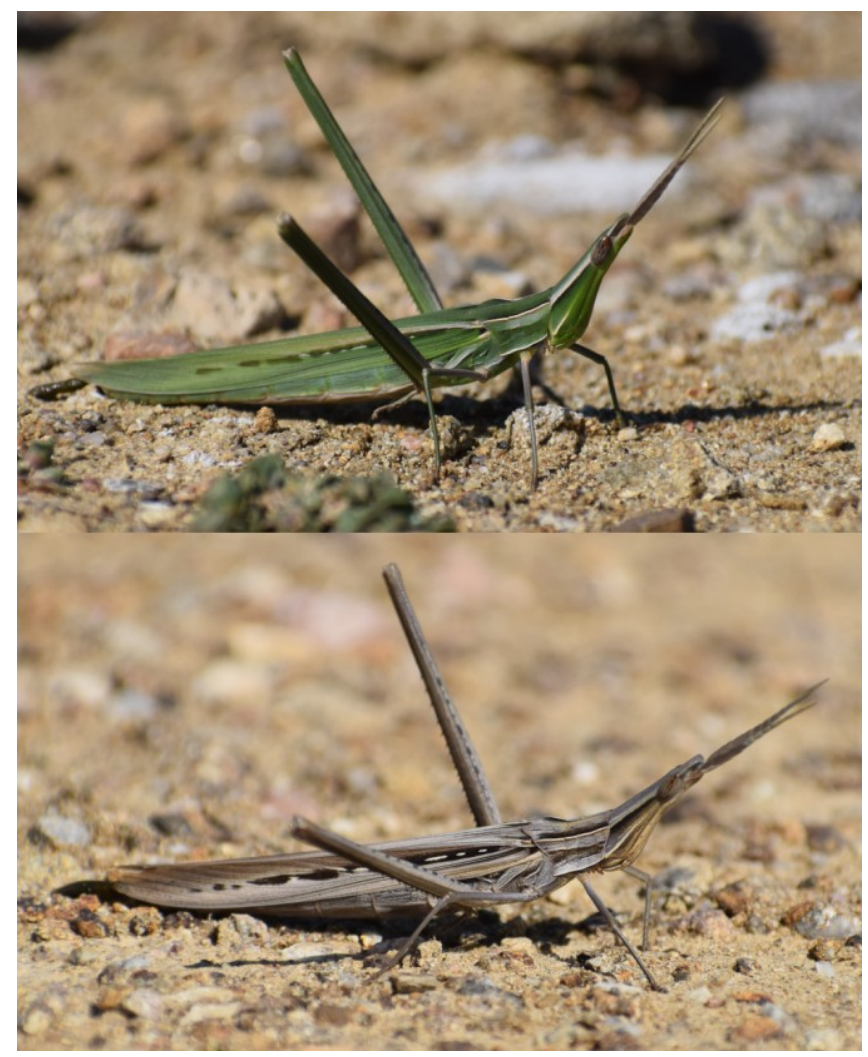

1. ábra. A sisakos sáska zöld és barna színváltozata a Nyugat-Mecsekben (Kővágószőlős, Kajdacs).

Figure 1. Green and brown color variations of Acrida ungarica from Kővágószőlös (Mecsek Mts). 


\section{Eredmények}

A sisakos sáska újabb faunisztikai adatai a Dél-Dunántúlról:

Mecsek, Kővágószőlős (2. ábra): Kajdacs, másodlagos szárazgyep, $220 \mathrm{~m}$ tengerszint feletti magasságban, N46,0758 ${ }^{\circ}$ E18, $1094^{\circ}$, 2019. augusztus 15., KOVÁCs A.: 3 q ; vízmütől délre zavart, gyomos szárazgyep útszegélyen és árokparton, $185 \mathrm{~m}, \mathrm{~N} 46,07202^{\circ}$ E18,11689 ${ }^{\circ}, 2019$. augusztus 20., PUSKÁS G.; Kajdacs, taposott és cserjésedő gyepek szántókkal körülvéve, 225 m tszfm., N46,07646 E18,10912 ${ }^{\circ}$ 2019. augusztus 20., PUSKÁs G.; Kajdacs, száraz gyepek, $225 \mathrm{~m}$ tszfm., N46,07681 ${ }^{\circ}$ E18, $11142^{\circ}, 2019$. augusztus 20., PusKÁS G.; rekultivált száraz gyep, $165 \mathrm{~m}$ tszfm., N46,06897 E18,10507², 2019. augusztus 20., PUSKÁS G.

Villányi-hegység: Villány, Somsich-hegy, másodlagos gyep szőlöültetvény mezsgyéjében (jelenlegi tájhasználat: kaszálás), $185 \mathrm{~m}$ tszfm., N45,873886 ${ }^{\circ}$ E18,441978 , 2019. szeptember 15., ERDŐS L., TOLNAY D.: 1 ㅇ․

\section{Értékelés}

A mecseki lelőhely a hegység nyugati részén, a Jakab-hegy déli lábánál található (2. ábra). A Kővágószőlőstől délnyugatra elhelyezkedő kiterjedt területen az észlelési pontok egy 40 hektár méretű poligonon belül helyezkednek el. Az elöfordulások többsége a települést a 6. sz. foúttal összekötő aszfalt úttól nyugatra található: a Kajdacs (Kajdács)dủlőben valamint a római kori villától délre található másodlagos gyepeken. Egy adat ettől az úttól keletre, a meddőhányó mellett, ruderális élőhelyről származik. Az összes helyszín az egykori uránbánya III. számú üzemének helyén található. A meddőhányók, zagytározók, ércdúsító üzem és a további ipari létesítmények rekultivációja az 1990-es és a 2000-es években zajlott (LENDVAINÉ KOLESZÁR et al. 2003). A gyeprekonstrukció helyenként homogén, de jelentős természeti értékeket is hordozó élőhelyeket eredményezett, a Kajdacs részben becserjésedett, változatosabb gyepein többek között a fokozottan védett magyar tarsza (Isophya costata BRUNNER VON WATTENWYL, 1878) populációját is megtaláltuk. A sisakos sáskának a Mecsekből eddig egyetlen előfordulását ismertük: 1957-ben Vékény közelében, a Csiszér-tetőnél (Keleti-Mecsek) került elő (NAGY 2006, SzÖVÉNYI et al. 2007). Az újonnan megtalált, nyugat-mecseki populáció eredete kérdéses. Jól repülő, ezért könnyen kolonizáló rovar, amelynek esetenként meglepő előfordulásaira bukkanhatunk (pl. Budapest belvárosában, PUSKÁS G. megfigyelése). A rekonstrukció eredményeként létrejövő szárazabb gyepek alkalmas élőhelyet biztosítanak számára, azonban a régióban eddig egyáltalán nem volt ismert populációja, ami forrásként szolgálhatna.

A Somsich-hegy Villány várostól közvetlenül ÉNy-ra elhelyezkedő, mintegy $185 \mathrm{~m}$ tengerszint feletti magasságú kiemelkedés. A gerincen ezüsthársas erdő, karsztbokorerdő valamint sziklagyepek fragmentumai találhatók, másodlagos cserjésekkel és gyepfoltokkal (TOLNAY 2016).

A Villányi-hegységben korábban a Szársomlyóról és a Fekete-hegyről volt ismert a sisakos sáska (KISFALI \& NAGY 2007); előfordulását a hegységből utoljára 1971-ben közölték 


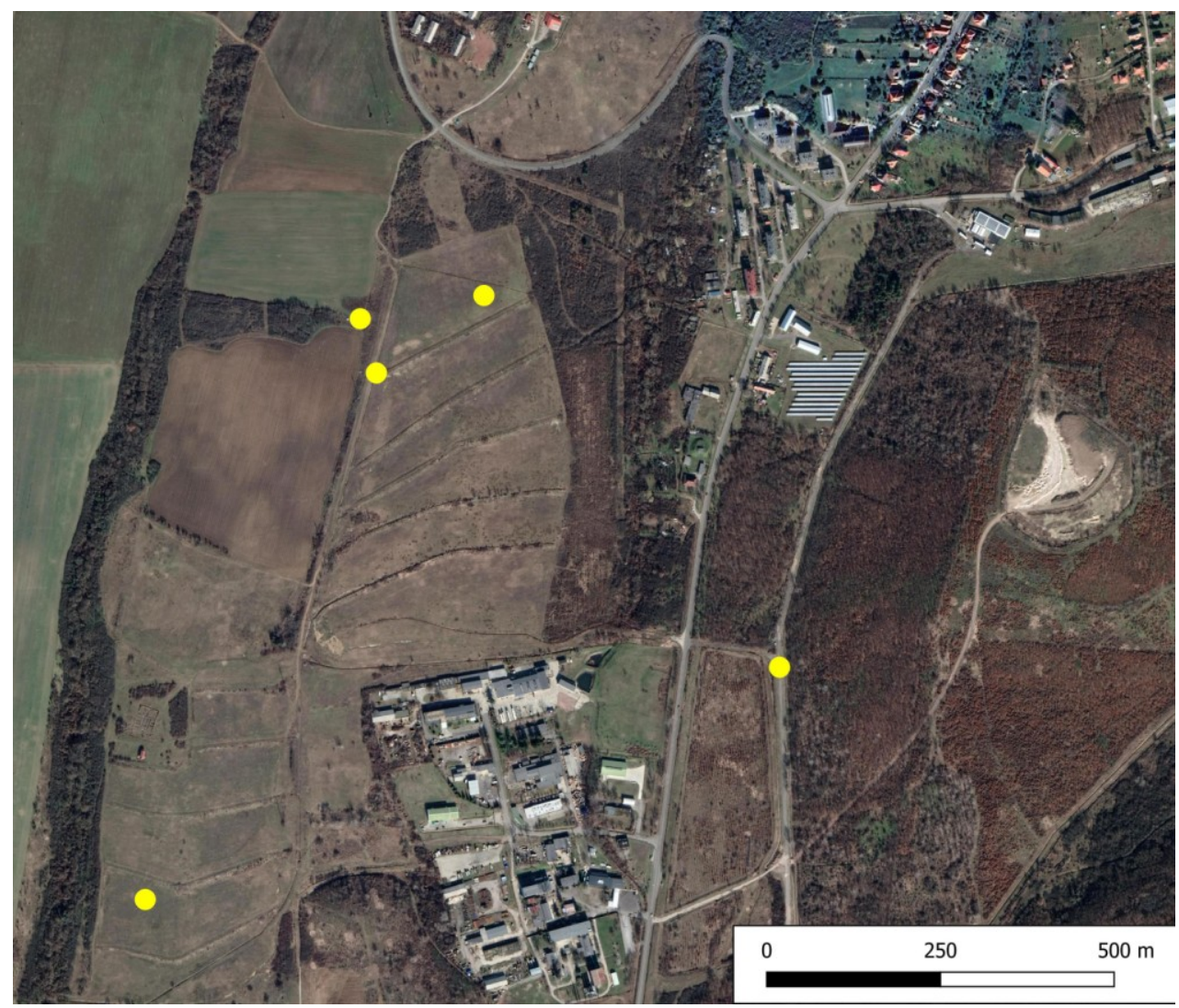

2. ábra. A sisakos sáska észlelési pontjai 2019 nyarán Kővágószőlős határában.

Figure 2. Observations of Acrida ungarica in 2019 near Kővágószőlős (Mecsek Mts).

(RÁCZ \& VARGA 1985, NAGY 1999, NAGY \& NAGY 2000). A jelen tanulmányban bemutatott terület a Fekete-hegytől keletre található. A faj fényképpel dokumentált recens adatai a környékről: a szársomlyói Szoborpark közelében: KOLLÁR (2018) és KUCSKA (2018) (KISFALI M. szóbeli közlése szerint ez a két megfigyelés minden bizonnyal ugyanarra a példányra vonatkozik).

Mind a mecseki, mind a villányi adatok egy országosan gyakori faj helyileg értékes, elszigetelt populációiról adnak hírt. Megőrzésük a szűkebb környék biodiverzitása szempontjából jelentős.

KENYERES (2019) szerint a sisakos sáska a Dunántúli-középhegységben egyre több helyről kerül elő, ami részben az intenzívebb kutatással, részben viszont az éghajlati változásokkal állhat összefüggésben. Mivel a Kárpát-medence éghajlata az előrejelzések szerint a következő évtizedekben lényegesen melegebbé és szárazabbá fog válni (BARTHOLY et al. 2008, PONGRÁCZ et al. 2011, MEZÖSI et al. 2016), elképzelhető, hogy ez hatással lesz a sisakos sáska elterjedésére. 


\section{Irodalomjegyzék}

ÁBRAHÁM L. 1992. A sisakos sáska (Acrida hungarica, Herbst 1786) a Boronka-melléki Tájvédelmi Körzet környékén. Dunántúli Dolgozatok Természettudományi Sorozat 7: 99-100.

Bartholy J., Pongrácz R., Gelybó G. \& Szabó P. 2008. Analysis of expected climate change in the Carpathian Basin using the PRUDENCE results. Időjárás 112: 249-264.

BIERINGER G. 2017. Nasenschrecke Acrida ungarica (Herbst, 1786). In: ZunA-KratKY T., Landmann A., Illich I., Zechner L., Essl F., Lechner K., ORTNer A., WeißMair W. \& WÖSs G.: Die Heuschrecken Österreichs. Denisia 39: pp. 581-584.

BiERINGER G., ZACHERL M. \& ZUNA-KRATKY T. 2018. Wiederfund der Nasenschrecke (Acrida ungarica) im Seewinkel. Ergebnisse der Erhebungen 2018. Bericht an den Nationalpark Neusiedler See - Seewinkel. Abteilung Forschung, Monitoring \& Citizen Science, Apetlon: 9 pp.

Deli,T. 2015. Sisakos sáska. Acrida ungarica (Herbst, 1786). In: Deli,T. \& DANYIK T. (ed.): A Körös-Maros Nemzeti Park állatvilága. Gerinctelenek. Körös-Maros Nemzeti Park Igazgatóság, Szarvas: pp. 322-323.

Hochkirch A., Chobanov D. P., Kleukers R., Rutschmann F., Kristin A., Szövényi G., Presa J. J. \& WiLlemSE L. P. M. 2016. Acrida ungarica. The IUCN Red List of Threatened Species 2016: e.T15037223A70632622. https://doi.org/10.2305/IUCN.UK.2016-3.RLTS.T15037223A70632622.en

HoluŠA J., KoČÁReK P., VLK R. \& MARHOUL P. 2013. Annotated checklist of the grasshoppers and crickets (Orthoptera) of the Czech Republic. Zootaxa 3616: 437-460. https://doi.org/10.11646/zootaxa.3616.5.2

KENYERES Z. 2006. Adatok a Dunántúli-középhegység egyenesszárnyú (Orthoptera) faunájának ismeretéhez II. (Data to the Orthoptera fauna of the Transdanubian Mountains II). Folia HistoricoNaturalia Musei Matraensis 30: 189-201.

KenYeRES Z. 2014. Adatok a Dunántúli-középhegység egyenesszárnyú (Orthoptera) faunájának ismeretéhez IV. (Data to the Orthoptera fauna of the Transdanubian Mountains IV). Folia HistoricoNaturalia Musei Matraensis 38: 47-55.

KENYERES Z. 2019. Adatok a Dunántúli-középhegység egyenesszárnyú faunájának (Orthoptera) ismeretéhez V. (Data to the Orthoptera fauna of the Transdanubian Mountains V). Folia HistoricoNaturalia Musei Matraensis 43: 81-88.

KenYeres Z., KisBenedeK T. \& SzÖvÉNYI G. 2013.: Orthoptera fauna of the Kisalföld (WesternHungary). Folia Historico-Naturalia Musei Matraensis 37: 47-64.

KenYeres Z., NAGy B. \& KinÁL F. 2014. Simontornya és környéke Orthopteroid faunája. In: SziTA É., Fetykó K., Kovács T. \& Horváth A. (ed.): Simontornya izeltlábúi. In memoriam Pillich Ferenc. Biodiverzitás-Kutató Társaság, Budapest, pp. 50-56.

KenYeres Z. \& RÁCZ I. A. 2011. A Bakonyi Természettudományi Múzeum egyenesszárnyú (Orthoptera) gyüjteménye. (Orthoptera collection in the Natural History Museum of Bakony Mountains). A Bakonyi Természettudományi Múzeum Közleményei 28: 81-104.

KisbenedeK T. 2015. Adatok a Janus Pannonius Múzeum Természettudományi Osztálya egyenesszámyú (Orthoptera) gyüjteményéböl. (Data from the Orthoptera collection of the Janus Pannonius Museum Natural History Department). A Janus Pannonius Múzeum Évkönyve 53: 27-38.

Kisfali M. \& NAGY A. 2007. Summary of the Orthoptera fauna of the Villány Hills (Southwest Hungary). A Janus Pannonius Múzeum Évkönyve 50-52: 48-57.

KRIŠTíN A., KAŇUCH P. \& SÁROSSY M. 2004. Grasshoppers and crickets (Orthoptera) and mantids (Mantodea) of sand dunes in the Danube lowland (S-Slovakia). Linzer Biologische. Beiträge 36: 273-286.

KOLLÁR L. 2018. https://www.izeltlabuak.hu/talalat/51406 (utolsó megtekintés 2020. október 31.) 
Krausz K. \& PÁPAi J. 2010. A Dél-Mezőföld Orthoptera együtteseinek összehasonlító elemzése. (Comparative analysis of the Orthoptera assemblages of the Southern-Mezöföld). Natura Somogyiensis 17: 141-152.

KUCSKA Zs. 2018. https://www.izeltlabuak.hu/talalat/46277 (utolsó megtekintés 2020. október 31.)

LENDVAINÉ KOLESZÁR Zs., HIDEG J. \& CSÁKI F. 2003. Kármentesitési füzetek 9. Szilárd ásványbányászati alprogram, Uránbányászat. Környezetvédelmi és Vízügyi Minisztérium, Budapest, 159 pp.

Mezősi G., Blanka V., Ladányi Zs., Bata T., Urdea P., Frank A. \& Meyer B. C. 2016. Expected mid- and long-term changes in drought hazard for the south-eastern Carpathian Basin. Carpathian Journal of Earth and Environmental Sciences 11: 355-366.

NaGy A. 1999. Data on the Orthoptera fauna of the Villány Hills, South Hungary. A Janus Pannonius Múzeum Évkönyve 43: 41-48.

NagY A \& NAGY B. 2000. The Orthoptera fauna of the Villány Hills (South Hungary). Dunántúli Dolgozatok Természettudományi Sorozat 10: 147-156.

NAGY A., RÁCZ I. A. \& ARNÓCZKYNÉ JAKAB D. 2019. A Hortobágy egyenesszárnyú (Orthoptera) faunájának kutatása és természetvédelmi szempontú értékelése. Tájökológiai Lapok 17(2): 219-231.

NAGy B. 1983. A survey of the Orthoptera fauna of the Hortobágy National Park. In: MAHUnKa S. (ed.): The fauna of the Hortobágy National Park. Akadémiai Kiadó, Budapest: 81-117.

NAGY B. 2006. A Mecsek Orthoptera faunájának jellegzetes vonásai. Natura Somogyiensis 9: 153-166.

NAGY B. \& SzÖVÉNYI G. 1998. Orthoptera együttesek a Körös-Maros Nemzeti Park területén. Crisicum 1: 126-143.

NAGY, B. \& SzÖvÉNYI, G. (1999): A Körös-Maros Nemzeti Park állatföldrajzilag jellegzetes Orthoptera fajai és konzervációökológiai viszonyaik. Természetvédelmi Közlemények 8: 137-160.

NAGY B. \& SzÖVÉNYI G. 2001. Somogy megye egyenesszárnyú rovarai (Orthoptera). (Orthopterafauna of Somogy county (SW-Hungary)). Natura Somogyiensis 1: 107-117.

NAGY B., SzÖVÉNYi G. \& PUSKÁs G. 2003. A Látrányi Puszta Természetvédelmi Terület egyenesszárnyú rovarairól (Orthoptera). (Grasshoppers (Orthoptera) of the Látrány Puszta Nature Conservation Area (W Hungary)). Natura Somogyiensis 5: 99-112.

PÁPAi J. \& KRAusz K. 2008. Tájökológiai vizsgálatok a Dél-Mezőföldi Tájvédelmi Körzetben az Orthoptera rovarok nyomán. (Landscape ecological study of the orthopteran insects in the Southern Mezőföld). Tájökológiai lapok 6(3): 311-322.

PongRÁCZ R., BARTHOLY J. \& MiKLós E. 2011. Analysis of projected climate change for Hungary using ensembles simulations. Applied Ecology and Environmental Research 9: 387-398. https://doi.org/10.15666/aeer/0904_387398

RÁcz I. A. 1986. Orthoptera from the Kiskunság National Park. In: MahunKA S. (ed.): The Fauna of the Kiskunság National Park. Akadémiai Kiadó, Budapest, pp. 93-101.

RÁcz I. A., NAGY A. \& JANCSEK E. 2005. Orthoptera collection of the Hungarian Natural History Museum (Budapest) II.: Caelifera. Folia historico-naturalia Musei Matraensis 29: 123-133.

RÁCZ I. \& VARGA Z. 1985. Adatok a Mecsek és a Villányi-hegység Orthoptera faunájának ismeretéhez. (Data on the Orthoptera fauna of Mecsek and Villány Mountains, South Hungary). A Janus Pannonius Múzeum Évkönyve 29: 29-35.

SzÖVÉnYi G., NAGY B. \& Puskás G. 2007. A Mecsek egyenesszárnyú rovar (Orthoptera) faunája és együttesei. Acta Naturalia Pannonica 2: 73-106.

SzÖVÉNYI G. \& PuskÁs G. 2011. Egyenesszárnyúak a Dél-Mezöföldön. In: IV. Dél-Dunántúl Zöld Szigetei - Konferencia a Dél-Mezöföldért. Energetikai Szakközépiskola. Paks. 2011. november 3. A konferencia elöadásainak összefoglalói: p. 15. 
TOLNAY D. 2016. A villányi Somsich-hegy természeti értékei, a veszélyeztető tényezők és természetvédelmi teendők. Kitaibelia 21: 55-62. https://doi.org/10.17542/21.55

VARGA Z., KASZAB Z. \& PAPP J. 1990. Rovarok - Insecta. In: RAKONCZAY Z. (ed.): Vörös könyv. Akadémiai Kiadó, Budapest, pp. 178-260. 


\title{
New data of Acrida ungarica (Orthoptera, Acrididae) from Southern Transdanubia (SW Hungary)
}

\section{LÁSZLÓ ERDŐS ${ }^{1,2}$, ATTILA KOVÁCS ${ }^{3}$ and GELLÉRT PUSKÁS ${ }^{4}$ *}

${ }^{12}$ Centre for Ecological Research, Institute of Ecology and Botany, 2163 Vácrátót, Alkotmány utca 2-4. ${ }^{2}$ MTA-DE Lendület Functional and Restoration Ecology Research Group, 4032 Debrecen, Egyetem tér 1.

${ }^{3}$ Hungarian Natural History Museum, Bakony Natural History Museum, 8420 Zirc, Rákóczi Ferenc tér 3-5.

${ }^{4}$ Hungarian Natural History Museum, Department of Zoology, 1088 Budapest, Baross utca 13.

*E-mail: saksup@gmail.com

ÁLLATTANI KÖZLEMÉNYEK (2021) 106(1-2): 000-000.

\begin{abstract}
Cone-headed grasshopper (Acrida ungarica) is protected by law in Hungary and also enlisted by the Hungarian Red List. We publish two newly revealed populations of the species from the Mecsek and the Villány Mts. Previously Acrida ungarica had just a single data from the Mecsek Mts. (collected in 1957), while it had two known localities in the Villány Mts. (reported last time in 1971).
\end{abstract}

Keywords: conservation biology, faunistics, Jakab Hill, xeric grasslands 